\title{
Markets for risk and openness to trade: how are they related?*
}

\section{5}

\section{Helena Svaleryd ${ }^{+}$and Jonas Vlachos ${ }^{++}$}

SSE/EFI Working paper Series in Economics and Finance No 327

If protectionist trade policies aim to insure domestic industries against swings in world market prices, the development of financial markets could lead to trade liberalization. Likewise, trade liberalization could lead to the development of financial markets that help agents diversify the added risks. In this paper, we empirically address the hypothesis that there is a positive interdependence between financial development and liberal trade policies. We find a positive and economically significant relationship between the two, with causation running in both directions. The results are, however, somewhat dependent on the measure of trade policy being used.

JEL Classification: F13; G20

Keywords: Financial markets; Trade policy; Panel data

\footnotetext{
* We thank Marcus Asplund, Tore Ellingsen, Lars Frisell, JoAnne Feeney, Almas Heshmati, Fredrik Heyman, Torsten Persson, two anonymous referees and seminar participants at the Stockholm School of Economics and Stockholm University for helpful suggestions. Mark Blake has provided excellent editorial assistance. Karen Lewis, Dani Rodrik and Romain Wacziarg have generously shared their data with us. Svaleryd thanks the Ahlström and Terserus Foundation, Vlachos thanks HSFR and the Swedish Institute for Banking Research for financial support.

${ }^{+}$Department of Economics, Stockholm University, 10691 Stockholm, Sweden. Email: hs@ ne.su.se.

${ }^{++}$Corresponding author: Department of Economics, Stockholm School of Economics, Box 6501, 113 83 Stockholm, Sweden. Email: jonas.vlachos@hhs.se.
} 


\section{Introduction}

It has long been argued that trade restrictions can be motivated by insurance considerations in the absence of full risk diversification. Examples are Corden (1974), Hillman (1977), Cassing (1980), Newbery and Stiglitz (1984), Eaton and Grossman (1985), Cassing et al. (1986). ${ }^{1}$ It follows that the development of institutions for risk diversification, e.g. financial markets, might reduce barriers to trade. Given the abundance of theoretical models, it is surprising that no empirical work has brought this hypothesis to the data. In this paper, we address the issue empirically and show that there exists a positive relation between openness to trade and the degree of financial sector development.

International trade brings about substantial changes in competition, technology, prices of intermediary and final goods, and in the long run even in factor endowments and the institutional features of a society. The exact outcome of trade liberalization for different individuals is therefore uncertain. Rodrik (1998) provides evidence that openness to trade also increases the permanent degree of income volatility in an economy. ${ }^{2}$ The theoretical papers mentioned above argue that trade barriers can be welfare enhancing if private markets fail to pool such risks. Feeney and Hillman (2001a) explicitly demonstrate how asset market incompleteness can affect trade policy in a positive theory of trade liberalization. In their model, the degree of portfolio diversification determines the protectionist lobbying effort conducted by owners of sector specific capital. If risk can be fully diversified, special interest groups have no incentive to lobby for protection and free trade will prevail. This model suggests a causal effect from financial development to trade liberalization. Another possibility is that the demand for insurance increases after liberalization, thus promoting the development of the financial sector.

In the light of this literature, we ask the question whether institutions allowing for better insurance possibilities and risk diversification within a country are positively related to a liberal trade regime. In particular, we investigate whether the development of domestic financial markets is systematically related to trade policy. Moreover, since openness to trade increases aggregate income volatility, we expect international financial integration to reduce the demand for trade protection. This hypothesis is also brought to the data. Due to the difficulties involved in measuring trade restrictions, we 
employ a number of different measures. The expected positive relation between financial development, both domestic and international, and openness to trade appears clearly for some indicators. For other measures, the results are weaker and only seem to apply to relatively rich countries. Causality is an important issue, albeit a difficult one to fully resolve using cross-national evidence. We find some support for a causal link from financial development to openness for trade, and some support for the opposite. These results are conditional on the indicator we use.

This paper is organized as follows. Section 2 provides an extensive theoretical and empirical motivation for the study. Section 3 outlines the empirical methodology, while Section 4 describes the data. Special attention is given to the measurement of trade policy and financial sector development. Section 5 presents the results and Section 6 concludes.

\section{Theoretical and empirical motivation}

As mentioned in the introduction, a number of papers deal with trade policy as an insurance device within a social planner framework. Feeney and Hillman (2001a), however, provide a positive theory of trade policy. Specifically, they model a twosector economy with independent productivity shocks that determine which sector will be exporting and import competing. Ex post the import competing sector can choose to lobby for protection and policy makers respond by implementing a tariff. The tariff increases the price for the import-competing good, but it also induces a consumption distortion in the economy thereby lowering aggregate welfare. In the standard case, when no portfolio diversification is possible, the equilibrium tariff will always be positive since the income gain from lobbying is larger than the consumption distortion for the import competing sector.

Next, domestic asset markets are introduced into this framework. Suppose that before the uncertainty regarding productivity is revealed, specific factor owners can trade in the asset markets. In the case when asset markets work without friction, the incentive for lobbying disappears since specific factor owners will optimally hold a fully diversified portfolio with specific capital from both sectors, and therefore only care about aggregate welfare. Suppose instead that the agents can only trade with a subset of capital. They may then be unable to reach a perfectly pooled equilibrium. The 
extent of lobbying and consequently tariffs will be determined by the difference between the income gain and the consumption distortion. Compared to the model without any trade in sector-specific capital, even limited access to capital markets reduces the payoff from protectionist policies. Thus, the degree of asset market incompleteness affects the lobby pressure for the imposition of tariffs and consequently how liberal a country's trade policies will be. Regardless of how susceptible the political sector is to private demand for protection, this effect will always be present. Given this setup, the empirical prediction would be a causal effect from financial development to trade liberalization. Another possibility is that the demand for financial services increases when the volatility of income goes up. In this case causality would run from openness to financial development.

The main focus of the Feeney-Hillman model is on domestic diversifiable risk and the functioning of domestic financial markets. The productivity shocks that hit the two sectors are independent implying that the risk can be domestically diversified. ${ }^{3}$ The assumption that a significant share of the risk facing the agents can be domestically diversified receives support in studies of output shocks and volatility. Ghosh and Wolf (1997) use US data to show that shocks to output growth in a particular industry in a particular state is mainly driven by shocks to the sector, and that these shocks are only slightly correlated across sectors. Hence there is scope for risk diversification between industries within a country using domestic financial markets. Using international data, Clark and Shin (2000) provide further support for this view by showing that the main source of variation in output and employment for an industry in a country is due to shocks to that industry in that country (as opposed to shocks common to the whole country or industry). By showing that shocks to the traded goods sector are larger than shocks to the non-traded goods sector, Ghosh and Wolf (1997) also provide indirect evidence that trade increase the volatility of output, i.e. support for the underlying assumption in the models mentioned in the beginning of this section.

The higher volatility of the tradable sector, compared to the non-tradable sector, is given a theoretical explanation in Traca (2000). ${ }^{4}$ In his model, productivity shocks hit both sectors. The tradable sector is also subject to price shocks, uncorrelated to the productivity shocks. When shocks hit the non-traded goods sector, prices move to offset the volatility of aggregate income. Since world market prices are given, no such 
offsetting mechanism is at work in the traded goods sector. Hence volatility in this sector is higher.

Although the main focus of this paper is the impact of domestic financial development on trade policy, it is obvious that an international dimension exists as well. If trade raises aggregate risk, as Rodrik (1998) argues, it is not possible to diversify this risk in purely domestic financial markets. Therefore, the amount of international risk sharing should also have a positive impact on openness to trade. In addition, Feeney and Hillman (2001b) observe that internationally open financial markets eliminate, or reduce, the interest in strategic trade policy. This being said, the literature on international risk sharing indicates that this effect is likely to be small. When summarizing the evidence, Lewis (1995) shows that the amount of consumption smoothing that takes place internationally is limited and that this amount is quite persistent over time..$^{5}$ Moreover, there is a strong 'home-bias' in equity holdings, suggesting that portfolios are not optimally diversified. ${ }^{6}$ One reason for this could be the blurred distinction between international and domestic financial markets. Due to the presence of internationally active corporations and the cross-listing of companies, it is possible that international diversification can be achieved within the domestic market. It is clear that whatever measures we use to capture the degree of domestic financial development, they will also capture this effect.

Another issue regarding international financial integration is concerned with the timing of liberalization events. The Feeney-Hillman model suggests that financial integration should precede trade liberalization. Generally, however, trade liberalization seems to precede or be simultaneous with international financial liberalization. ${ }^{7}$ In practice, it is difficult to separate trade and financial liberalization from each other. As shown by Tamirisa (1999), capital controls can effectively work as an impediment to trade. Thus, measures of financial openness, rather than explaining trade policy, may be part of what we wish to explain. Since trade and financial liberalization can be part of the same policy, questions concerning the timing between the two types of events are hard to sort out. ${ }^{8}$ 


\section{From Theory to Estimation}

There are, of course, other determinants of trade policy besides the concern for insurance. The optimal tariff argument makes it clear that countries (economically) large enough to affect international goods prices can increase their welfare by the introduction of a tariff. In a related vein, Alesina and Wacziarg (1998) argue that the cost of self-sufficiency is lower for large than for small countries. Countries with large markets should therefore be less open to trade than countries with small domestic markets. As the demand for variety in the choice of goods is likely to increase with wealth, per capita GDP is another probable determinant of trade policy. ${ }^{9}$ This leaves us with the following basic trade policy equation to estimate:

\section{Trade Policy $=f($ Market Size, GDP, Financial Development $)$}

Since the institutional environment is roughly the same for all sectors within a country, and risk diversification is essentially an inter-sector activity, the natural level of comparison is between countries. It is of course possible that the need and the opportunities for risk diversification differ between industries. However, since it is unclear in what way industries differ, we argue that the most suitable approach is to use country level data. Thus, we analyze how aggregate measures of financial development affect the aggregate trade policy choices made in a country.

Due to the level of aggregation, it is possible neither to discriminate between different sources of uncertainty, nor to be explicit about the mechanism that causes financial development to affect openness to trade. What is possible, however, is to control both for aggregate risk caused by openness and for aggregate income uncertainty. This is of importance since domestic asset markets cannot diversify aggregate risk.

A standard cross-section approach has the disadvantage of being a static approach to the essentially dynamic problem of financial development and trade policy. To allow for a time dimension, we make extensive use of panel data. Panel data has a number of advantages compared to both cross-section and time-series analysis, the most obvious being the ability to control for time and country specific fixed effects. In addition, the panel approach allows us to undertake causality tests, which are not possible in a cross-section setting. 


\section{Measurement issues and data}

We now turn to the problem of how to measure trade policy and financial sectors with the available data.

\subsection{Measuring trade policy}

There is a huge literature discussing the pros and cons of different aggregate measures of the restrictiveness of trade policy (see e.g. Harrison 1996). The conclusion to be drawn from these studies is that no fully satisfactory measure is available. For our purpose, the measures should be objectively comparable across countries and time.

A popular direct measure of trade policy is the Sachs-Warner (1995) index. In their study of the period between 1950-94, a country is judged as open when it does not fulfill any one of the following criteria: (i) average tariffs are higher than 40\%, (ii) non-tariff trade barriers cover more than $40 \%$ of imports, (iii) the economic system is considered socialist, (iv) major exports are monopolized by the state, and (v) the black market exchange rate premium exceeded 20\%. The fraction of years between 1950-94 when the country is judged as open is then used to construct the index. A problem with the Sachs-Warner indicator is that it only considers the discrete nature of trade policy and not the degree of restrictiveness. Moreover, the different criteria might not be equivalent when evaluating the protectionist impact of trade policy. A more serious criticism of the Sachs-Warner index is put forward by Rodriguez and Rodrik (1999). They argue that the index serves as proxy for a wide range of policy and institutional differences and not only of trade policy. Despite these criticisms we will make use of the index, since it attempts to handle the problem of aggregating and combining different aspects of trade policy coherently across countries and time.

The second indicator of trade policy to be used is openness, measured as the ratio of the sum of imports and exports to GDP. Openness itself is not a measure of trade policy since trade is determined by other factors than policy. Lee (1993) constructs a simple measure of free trade openness, which controls for distance to the world's major trading economies and land area. The main advantage compared to the incidence measures is that all relevant trade restrictions are captured in a single, aggregate measure. The most obvious shortcoming here is the hypothetical 
counterfactual under free trade, making the measure sensitive to misspecifications of the trade equation. Despite these limitations, we will follow Lee and control for structural features of the economy and use trade share to GDP as a measure of trade policy (OPEN in this paper).

In addition to the measures described above we make some use of other indicators of trade policy. First, the ratio of import duty revenue to the value of total imports (IMPDUT) is used as a proxy for effective import tariffs. The main problem with the import duty ratio is that it does not have a linear relation to the effective degree of protection. If tariffs are prohibitive, they will not show up in this measure. Further, especially in poor countries, trade taxes are an important source of government revenue. Finally, a drawback with all measures based on tariffs is that many restrictions on trade are not tariff-based. The second additional measure of trade policy, the pre Uruguay round non-tariff trade barriers (NTB), tries to remedy this problem. This is not unproblematic since it disregards the use of tariffs as impediments to trade. Moreover, the cover ratio is just an indicator of the share of all traded goods that are subject to quotas and similar restrictions. This means that nothing can be said about whether these restrictions are binding or not.

\subsection{Measuring financial development}

The purpose of the paper is to investigate whether the financial system, in its role as an insurance mechanism, is correlated with trade openness. Thus, we need a measure describing the financial systems ability to hedge, diversify, and pool risks.

The possible proxies for financial development can be divided into three different categories: the size of financial sector, the financial systems ability to allocate credit, and the real interest rate. Since the real interest rate is largely affected by macroeconomic factors, it will not be used in this study. A general problem with sizebased measures is that the size of the financial sector does not necessarily measure its capacity to diversify risk.

The most popular measure for size of financial sector is the ratio of liquid liabilities to GDP, labeled LLY in this paper. A potential problem with this measure is that it can be too high in countries with undeveloped financial markets, since no other value- 
keeping asset than money exists. To allocate credit is a major function of the financial sector, especially the banking industry. Proxies focusing of the financial system's ability to allocate credits have been developed by for example King and Levine (1993). Since we are interested in the financial system's ability to diversify private sector risk, we will use credit issued to private enterprises divided by GDP, and label it DC.

Another measure focuses on the stock market. Levine and Zervos (1998) measure stock market capitalization by the value of listed companies on the stock market as share of GDP in a given year (here labeled MCAP). Although large markets do not necessarily function effectively, many researchers use capitalization as an indicator of stock market development. Compared to the other measures, MCAP is intuitively better related to the underlying idea of portfolio diversification than LLY and DC. Unfortunately, this variable is not available prior to 1975 , and the number of countries for which MCAP is available is also more limited than for LLY and DC. The correlations between LLY, DC, MCAP, and GDP (among other variables) are presented in Table A2. ${ }^{10}$

\subsection{Measuring the possibilities of international risk-sharing}

In their report Exchange Arrangements and Exchange Restrictions, the IMF annually summarizes the restrictions on international capital markets that each country imposes. These indicators are given the number one if a certain restriction is imposed, and zero otherwise. Although the binary nature of these indicators makes them less than ideal, they are the only available measure for a wide range of countries over time (we have data from between 1967-1993). Moreover, they have been found to have significant explanatory power on international consumption risk sharing (Lewis 1996), thus making them suitable for our purposes. In order to account for the differences in the degree of restrictiveness between countries, the simple annual average of four indicators is calculated and labeled CAPCONT. ${ }^{11}$ These annual averages are then converted into five-year averages in order to fit the rest of the data.

\subsection{Scope of the data set}

The panel in this study is constructed for the years 1960-1994. To smooth short-term fluctuations, and to fill gaps in the series, all time varying variables are averages over 
five year periods. The selection of countries is based on the widely used Barro-Lee (1994) data set, which contains data for 138 countries. Data availability restricts the sample for some regressions to around 80 countries (for more details on the data, see Table A1 in the Appendix). When running panel regressions, we first remove countries for which one or more variables are available for one (or no) time periods. This procedure allows us to make better comparisons between fixed and random effects estimations. We also check for outliers and in the panel study remove Hong Kong and Singapore in the regressions with OPEN as dependent variable. This is done because these countries display an extreme degree of trade, which largely consists of transit trade.

\section{Results}

Now we are ready to formulate the specifications we would like to estimate. Theory predicts that there will be a positive relation between well developed financial markets and openness to trade, even when controlling for other determinants of trade policy.

\subsection{The Sachs-Warner index}

We begin by looking at the Sachs-Warner index. Given the discussion in Section 2, we use land area and population as proxies for country size, and GDP per capita as a measure of wealth. According to theory, the size proxies should have a negative effect and GDP a positive effect on openness. Moreover, we include dummies for geographical region (OECD, East Asia, Latin America and Sub-Saharan Africa) and proxies for financial development in the regression. In line with our hypothesis, we expect the proxies for financial development to enter with a positive sign. Since the Sachs-Warner index is an aggregate index based on the fraction of years a country has been open since 1950, we can not take the time variation of the variables into account. Since it is not obvious which time period to use in OLS regressions, we use the average of the explanatory variables to estimate the following equation:

$$
\text { Sachs-Warner }_{i}=\alpha+\beta_{1} A R E A_{i}+\beta_{2} P O P_{i}+\beta_{3} G D P_{i}+\beta_{4} F D_{i}+\beta_{5} \text { Region }_{i}+\varepsilon_{i}
$$


where $F D_{i}$ is one of our measures of financial development. The results from the estimations are presented in Table 1. The coefficients on LLY and DC are positive and significantly different from zero, as expected. MCAP, however, is not significant on conventional levels. One possible explanation is that the MCAP sample mainly includes relatively rich countries, which score high on the Sachs-Warner index. Per capita GDP is positive, but not statistically significant. Population enters, as expected, negatively into the regressions although not always statistically significant. The other proxy for size - area is never significant. Due to the construction of the index, the interpretation of the coefficient values of 0.52 and 0.37 is not fully clear. In the full sample of observations, the medians of LLY and DC are around 29 and 22, with standard deviations of 24 and 26, respectively. The median of the Sachs-Warner index is 17. An increase in LLY or DC by approximately one standard deviation (25 percentage points) would yield an increase in the index by about 10 points. For a country around the median of the Sachs-Warner scale (Philippines), an increase of 10 points means getting ahead of 12 countries in the openness ranking. Thus, the results indicate a strong positive relationship between openness and financial development.

(Table 1 here)

As discussed in Section 2, we would like to control for international financial openness. The measures at hand, however, partly overlap with the Sachs-Warner index and should thus not be included in the regressions. However, if we nevertheless include the measure CAPCONT, the results remain virtually unchanged.

As mentioned in Section 2, causality may run either from financial development to trade liberalization or the other way around if the demand for insurance increases after the switch of trade regime. Since the Sachs-Warner measure is constructed as an average over the period 1950-1994, it is not obvious how to investigate the question of causality between financial development and trade liberalization using this index. In Table 2, we show the percentage change in financial development for the five-year periods preceding and succeeding the actual date of liberalization (most countries just liberalize once and then remain open). ${ }^{12}$ The first two rows indicate that after an economy moved from closed to open according to the Sachs-Warner index, financial development accelerated. From the bottom two rows, however, we read that the 
countries that are open during the whole period have a higher initial level of financial development than closed countries. Investigating in this way shows that the direction of causality seems to run from trade liberalization to financial development. This indicates that the demand for the services provided by the financial sector increases after trade liberalization. Another possibility is that Rodriguez and Rodrik (1999) are correct when criticizing the Sachs-Warner index for reflecting a general switch to market friendly practices. ${ }^{13}$

(Table 2 here)

\subsection{Openness: cross-sectional results}

The other approach chosen to investigate whether financial markets affect trade policy is to use the direct measure of trade, i.e. OPEN. Since actual trade is not a measure of trade policy, we control for structural factors such as population and area. Not only does country size affect trade policy, it also affects the country's propensity to trade. This assumption is based on gravity models, which show that, everything else being equal, large countries will tend to trade less than smaller ones. GDP per capita is included given the reasons presented in Section 3. We use the measure of aggregate distance as a proxy for transportation costs, since high transportation costs are likely to decrease trade by making it less profitable. Finally, regional dummies are included. This gives us the following baseline cross-section specification:

$$
\mathrm{OPEN}_{i}=\alpha+\beta_{1} \mathrm{AREA}_{i}+\beta_{2} \mathrm{POP}_{i}+\beta_{3} \mathrm{DIST}_{i}+\beta_{4} G D P_{i}+\beta_{5} F D_{i}+\beta_{6} \text { Region }_{i}+\varepsilon_{l}
$$

The results from cross-sectional regressions on 1990-94 data are presented in Table 3. We estimate the baseline regression both with and without the inclusion of measures of financial development. In the presented regressions, all variables are in logs. We can motivate a log specification on theoretical grounds: it is reasonable to assume that the risk reducing effect is more important when starting from a low degree of financial development. ${ }^{14}$ The results, however, are not contingent on the $\log$ specification. In the baseline openness equation (column 2), population and distance indeed come out with the expected negative sign. Moreover, the proxy for financial 
markets, LLY, is statistically significant and positive as predicted by theory. In columns 3 and 4, we show that this relationship holds for both DC and MCAP as well.

Comparing columns 2 and 3, we see that the adjusted $\mathrm{R}^{2}$ increases by 8 percentage points when adding LLY to the openness equation, implying that multicollinearity between GDP and LLY is not what is driving the results. ${ }^{15}$ Further, we see that the point estimates vary quite a bit between the proxies, making it difficult to judge the effect of the development of financial markets on trade. Moreover, it must be remembered that we are dealing with proxies, making the interpretation of the slope coefficients slightly unclear. However, if we consider the point estimate of $0.412,{ }^{16}$ then an increase in LLY by 10 percent of GDP would imply an increase in the trade to GDP ratio by 4 percentage points. To get some further intuition about the size of this effect, note that the median values of LLY and OPEN in the period 1990-94 are around 40 and 60, with a standard deviation of 27 and 41, respectively. Increasing LLY by one standard deviation would then be associated with an increase in the trade to GDP ratio by 11 percentage points. For the country with median openness, this is an increase in the trade share of GDP by 18 percent. Repeating this exercise for DC and MCAP shows that an increase by one standard deviation in the respective variable would increase OPEN by 7 and 5 percentage points respectively. All in all, these estimates indicate that an increase by one standard deviation in financial development increases openness to trade by between 8-18 percent for a country with median openness.

(Table 3 here)

The relationship between LLY and OPEN holds for all cross-sections except the 1960-64 period. For DC, the result is somewhat weaker, although still pretty strong. In 1985-89, the effect is borderline significant (p-value 0.115) and it fails to hold in 1960-64 and 1965-69. MCAP is strongly significant, both in the 1980-84, 1985-89 and 1990-94 periods. In the first period of availability, 1975-79, MCAP is not significant. In this period, the very small sample of countries is likely to be part of the explanation. Since MCAP is the proxy closest to our idea of portfolio diversification, it is encouraging for the hypothesis that it remains significant at the $1 \%$ level in the three last time periods. 
Aggregate vs. diversifiable risk

In Section 2, the difference between domestically diversifiable risk and aggregate risk was discussed. Domestic insurance markets cannot diversify aggregate risk - access to international insurance markets is necessary for that purpose. In Table 4, we show the result of some tests for LLY and MCAP that consider these issues. ${ }^{17}$ In the first column we add the index of international financial openness. The sign of this variable is negative (although not significant) as we would expect it to be if access to international financial markets helps facilitate an open trade policy. Including the variable CAPCONT does not affect the estimates of LLY and MCAP. In the next two columns, we control for variables likely to increase aggregate external risk. The first of these variables is an index on the product concentration of exports, $\mathrm{CI},{ }^{18}$ the second the share of primary exports of all exports, PRIMSH. It is reasonable to assume that a high value on either of these variables will increase aggregate income volatility caused by price movements on the international markets. Since domestic risk markets cannot diversify aggregate risk, controlling for external risk is the equivalent to controlling for non-diversifiable risk. The inclusion of these variables does not affect the results for LLY or MCAP. In the last column we include the share of foreign direct investments to GDP, FDI, in order to account for the possibility of a spurious correlation between financial development and trade. ${ }^{19}$ It is plausible that FDI is positively related to both trade and financial development. This inclusion does not affect the basic results.

(Table 4 here)

\subsection{Openness: panel results}

By using a panel of data, we can go beyond the simple cross-section approach, controlling also for time and country specific effects, as well as bringing time into the analysis. The baseline panel specification is:

$$
\begin{gathered}
\text { OPEN }_{i t}=\alpha+\beta_{t} A R E A_{i}+\beta_{2} P_{P O P_{i t}}+\beta_{3} D I S T_{i}+\beta_{4} G D P_{i t} \\
+\beta_{5} F D_{i t}+\beta_{6} \text { Region }_{i}+\lambda_{t}+v_{i}+\varepsilon_{i t}
\end{gathered}
$$


Where $\lambda_{t}$ is a time-specific effect, constant over countries, $v_{i}$ is a country-specific effect, constant over time, and $\varepsilon_{i t}$ is the usual residual. AREA and DIST will not be included in fixed effects estimations since these variables are time-invariant and can hence not be distinguished from the country specific effects. We introduce further variables later on.

The baseline panel results are presented in Table 5. The results are very similar to the ones in the cross-country setting, although the point estimates on our proxies for financial development are somewhat smaller. We have also run random effects regressions, but since these results are similar to the fixed effect estimations, we do not present them. ${ }^{20}$ More generally, the fixed effects approach is an attempt to account for the changes in openness which have occurred between 1960-94. To account for these changes, we would need more (time varying) explanatory variables than the ones we have included in the baseline regressions. However, the result that financial development is positively related to openness, even after controlling for both fixed country effects and time-specific events, is encouraging for our basic hypothesis.

(Table 5 here)

Aggregate risk, once again

To check the robustness of the panel results, especially with respect to aggregate and domestically non-diversifiable risk, we continue our study by including additional control variables. The results from these regressions are reported in Table $6 .{ }^{21}$ The first variable we include is CAPCONT, the index capital controls. As we would suspect, the sign of the coefficient is negative, although the statistical significance varies between specifications. The negative sign gives support for the hypothesis that international risk sharing is an important determinant of trade policy. In Section 2 we mentioned some caveats with this measure. Most importantly, capital controls can effectively work as trade restrictions, thus belonging on the left-hand side of the regression. However, regardless of the exact mechanism involved, the sign should be negative. Domestic financial markets still have a positive and significant impact on trade in all specifications. Hence we can conclude that the basic result is not due to a correlation between international financial restrictions and financial development. 
Both the development of domestic asset markets and the integration on international financial markets have independent effects on openness to trade.

(Table 6 here)

Next, we include TOT, terms of trade shocks. TOT is defined as the growth rate of export prices minus the growth rate of import prices. We would expect the sign of this coefficient to be positive: a country is likely to trade more if export prices are rising and import prices are falling (or growing at a slower rate). This prediction is supported by the data and the inclusion of TOT does not affect the point estimates of LLY and MCAP (TOT is not included in the baseline specification since it is not available for the full time period).

In the cross-section regressions we had to rely on export concentration, CI, and the share of primary resources in exports, PRIMSH, as proxies for aggregate external risk. The panel setting allows for more direct ways of approaching this problem. In columns 5 and 6 of Table 6, we control for total aggregate risk as measured by the standard deviation of per capita GDP during the period 1960-92. The variable is not significant and does not affect the coefficients on LLY or MCAP. In the last two columns, we control for aggregate external risk, measured by the standard deviation of terms of trade multiplied by average openness. Given its construction, it is of no surprise that this variable is positively related to openness. Since the key estimates are not affected by these inclusions, we conclude that the effect of financial markets on openness is not caused by a correlation with external risk. Rather, the stability of the coefficient even after the inclusion of aggregate risk measures indicates that domestic risk sharing is what matters for openness. As our controls for aggregate risk are timeinvariant, we must use the random effects estimator for the last four regressions. ${ }^{22}$ For these estimations, we perform the Hausman specification test. If the empirical model is correctly specified, and the Hausman test returns a significant result, this can be interpreted as evidence that the individual specific effects and the regressors are correlated and hence that fixed effects estimation should be used. As can be seen in the last row of Table 6, the Hausman test indicates that the random effects estimator is appropriate for the LLY regressions, but not for the MCAP regressions. Despite this limitation, we conclude that domestic asset markets have an independent positive 
relation with openness to trade, and that access to international asset seems to have a positive impact on trade, although this result is somewhat weaker.

\section{$\underline{5.4 \text { Alternative measures of openness }}$}

As discussed above, there are many possible, but no ideal, measures of openness that have been used in the literature. Before moving on to issues regarding causality and simultaneity, we take a look at the measures IMPDUT and NTB's. ${ }^{23}$ Although direct indicators of trade policy, these measures suffer from drawbacks mentioned in Section 4.1. For these reasons, and for the lack of very interesting results, this section is kept brief.

There are good reasons to expect the use of these barriers to vary between rich and poor countries. Therefore, we split the sample according to average per capita GDP (for the relevant time period). Since no significant effects are found for the full sample of countries for any of the trade policy indicators, Table 7 only includes the subsample regressions. When using the proxy LLY for financial development, no significant results are found in any specification (the same is true when using DC). When using MCAP, our favored measure, we see from columns one and three that the variable enters with the predicted sign in the sub-sample of relatively rich countries. The absence of results for poor countries could reflect their reliance on trade taxes as a source of government revenue. Since trade-related risk may also be diversified on international markets, we also include the measure of international financial integration, CAPCONT, to the regressions (not presented). NTB-cover ratios are not affected by this inclusion. We do find support for the hypothesis in rich countries, when import duties is used as a measure of trade policy. However, when both CAPCONT and MCAP are included in the regressions, the latter loses its significance.

It must be kept in mind that these results only apply for a sub-section of the sample and that they are quite weak. Despite this, they do point in the direction suggested by theory. The weak concordance with the results for OPEN and the Sachs-Warner index partly reflects the difficulties in putting a single number on a country's aggregate trade policy. However, it also suggests that financial development has a stronger link to trade than to trade policy. 
(Table 7)

\section{$\underline{5.5 \text { Causality }}$}

So far, we have established a strong relationship between our proxies for financial development and openness to trade, but have not mentioned issues of causality and simultaneity in relation to the variable OPEN. Finding a causal link from financial development to trade would lend specific support for the Feeney and Hillman (2001a) hypothesis. The reverse causality, from trade to financial development, would not, however, contradict the underlying theoretical reasoning. Increased exposure to the fluctuations of the international market could increase the demand for portfolio diversification. Finally, one can easily imagine political decisions affecting both variables simultaneously.

In order to explore the causality aspects, we first turn to the concept of Granger causality tests. The Granger test amounts to checking whether the lagged independent variables are jointly significant in a regression of the dependent variable on its own lagged values, i.e. a regression of the following kind:

$$
y_{i t}=\alpha_{0}+\sum_{r=1}^{n} \alpha_{r} y_{i t-r}+\sum_{r=1}^{n} \beta_{r} X_{i t-r}+v_{i}+\varepsilon_{i t}
$$

The inclusion of the lagged dependent variable on the RHS creates a dynamic panel data problem: the lagged dependent variable is correlated with the fixed effect. To eliminate the bias caused by the presence of fixed effects, the equation is estimated in first differences. Since first the differentiation induces MA(1) residuals, the lagged difference of the dependent variable has to be instrumented for. This will be done using the twice-lagged difference and the twice-lagged level of the dependent variable as instruments. ${ }^{24}$

The estimates presented in Table 8 include only one lag, since 5-year averages make the time series rather short. Columns 1 and 2 show that the causality runs both ways. LLY and DC do Granger-cause openness, but there is also an effect of openness on the two proxies for financial development. MCAP, however, does not Granger-cause 
OPEN instead the causality clearly runs in the opposite direction. Thus, which conclusion to draw depends on which proxy is used. Judging by the result for DC and LLY, there is an effect of financial markets on trade, while MCAP shows that there is no such effect. It should be kept in mind that we have very few time-periods available when testing for causality using MCAP.

(Table 8)

\section{$\underline{5.6 \text { Simultaneity }}$}

In order to take into account the possible simultaneity, we use instruments for financial development to see if the exogenous component of each of the proxies is significant. Finding instruments for financial development that are not correlated with trade policy is not an easy task. LaPorta et al. (1997) have, however, come up with a number variables that could possibly serve our purposes. Unfortunately, these variables are all time-invariant, making panel regressions impossible. ${ }^{25}$ Instead we limit our focus to the 1990-94 cross-section and attempt to instrument for our three proxies of financial development. The instruments we use are: (i) an index of minority shareholder protection that takes a value between 0-6 with a higher value indicating stronger minority rights, (ii) a 'rule of law' index constructed by the risk rating agency International Country Risk (ICR) that assesses the law and order tradition of a country and ranges between 0-10, with lower scores for less tradition of law and order, and (iii) the number of assassinations per million inhabitants. We use these instruments in order to capture the ideas that the protection of shareholders, an effective legal system, and a relatively safe environment are crucial elements for the development of financial markets. Why these instruments should have a relation to trade policy is less clear, and below we test for an independent effect of the instruments on openness to trade. Using these instruments limits the number of observations, and we end up with 36-38 countries in the regressions. Even though the sample is limited, we see in Table 9 that LLY, DC, and MCAP are all significant with the expected sign. The level of significance in a bit lower than in the OLS-estimations, but this should be of no surprise since we lose efficiency by using instrumental variables. Compared to the OLS-estimates in Table 3, all point estimates are much larger, suggesting elasticities between $0.2-0.6 .^{26}$ 
(Table 9 here)

In order to account for the validity of the instruments, we also report the test statistics from the Hansen over-identification test in Table $9 .{ }^{27}$ Since the $10 \%$ critical value equals 4.61 , all three IV-regressions pass the test by a wide margin.

Using the instrumental variables of financial development on the Sachs-Warner index does not yield any significant results. One reason could be that the instruments are from the late 1980's or the early 1990's, while the Sachs-Warner index is an average between 1950-1994. Thus, even if the results had been significant, we would have had reasons to question the exogeneity of the instruments.

These results are broadly consistent with the results on Granger causality. LLY and DC Granger cause OPEN, and have an exogenous effect on OPEN when using instrumental variables. MCAP seems to have an exogenous effect on openness, even though the Granger tests tell a different story.

Finally, we consider the possibility that both openness and financial development are simultaneously caused by the same underlying variable, not yet included in the regressions. One obvious possibility is that market friendly policies in general could affect both financial development and trade policies. To control for this, an index of "regulatory burden" described in Kaufmann et.al. (1999) is added to the regressions. This index is a combination of measures of market unfriendly practices. Further, dummy variables of a country's legal origin as described in LaPorta et.al. (1997) are included on the right hand side of the regressions. The inclusion of these variables does not affect the results and the regressions are not presented.

\section{Conclusion}

Previous work on the relation between trade policy and financial markets has been purely theoretical. This paper is a first attempt to empirically investigate the interdependence between financial development and openness to trade. Our major finding is that there does exist an economically significant relationship between these variables. In addition, the degree of integration on international financial markets has 
an independent effect on openness to trade. However, the results are somewhat dependent on the measure of trade policy that is used.

The positive relation is shown to hold both when the Sachs-Warner index and when structurally adjusted trade are used as measures of openness. The results are robust for a variety of specifications and econometric techniques. For proxies of tariff levels and non-tariff trade barriers the results are weaker and only hold for relatively rich countries. Evidence of simultaneity between trade and financial development is found, and the direction of causality seems to be running both from financial development to the volume of trade and in the opposite direction. Considering the possible simultaneity, we find support for an exogenous effect of financial markets on openness to trade using instrumental variables. However, when looking at trade liberalization according to the Sachs-Warner index, we find that financial development is stronger after, rather than before, the liberalization event. Despite our efforts to establish causality the results are inconclusive and hence the exact mechanism behind the effect is not revealed in this study. This is perhaps not surprising since issues concerning causality are notoriously difficult to settle using cross-national panel data.

This paper can be seen as a complement to the recent literature suggesting that risk reducing policies and trade policy is interdependent. In an oft-quoted paper, Rodrik (1998) presents theoretical and empirical arguments that countries more open to trade show greater fluctuations in income, and that the government sector is expanded in order to reduce these fluctuations. Since risk is aggregate in his model, private risk diversification within a country is not possible. Rodrik argues informally and shows empirically, however, that policies that reduce risk between groups within a country are also an important response to openness to trade. Agell (1999) follows the same line of thought when showing that open countries are more prone to provide insurance through labor market regulations than closed ones. The common theme in these two papers is that risk-increasing policies can be optimally combined with policies reducing risk. Our paper makes the point that there may be interdependence between opportunities for private risk diversification and risk-increasing policies. This point should apply to other areas than trade policy and is of interest when discussing, among other issues, the timing and political feasibility of policy reform. 
Our results qualify some conclusions drawn in the recent literature. Both Agell (1999) and Rodrik (1997) warn that the current trend towards globalization of economic activity leads to a greater exposure to risk, and thus greater demand for risk-reducing reforms, while simultaneously reducing the scope for government interventions especially through taxation and labor-market regulations. However, globalization also encompasses financial markets. If domestic asset markets and the integration of international asset markets facilitate liberal trade policies, as our results suggest, better domestic and international financial markets may well alleviate the negative effects of globalization pointed out by Agell and Rodrik. 
Table A1. Descriptive statistics

\begin{tabular}{|c|c|c|c|c|c|}
\hline $\begin{array}{l}\text { Variable } \\
\text { (years available) }\end{array}$ & Description & Source & Mean & $\begin{array}{l}\text { Standard } \\
\text { deviation }\end{array}$ & $\mathrm{N}$ obs \\
\hline $\begin{array}{l}\text { Assassina- } \\
\text { tions }\end{array}$ & $\begin{array}{l}\text { Number of assassinations per } \\
\text { million inhabitants }\end{array}$ & $\begin{array}{l}\text { World } \\
\text { Bank1 }\end{array}$ & 0.261 & 0.474 & 70 \\
\hline $\begin{array}{l}\text { AREA } \\
(1960-94)\end{array}$ & Land area in $\mathrm{km}^{2}$ & WDI & 761052 & 1693138 & 134 \\
\hline $\begin{array}{l}\text { CAPCONT } \\
(1967-92)\end{array}$ & $\begin{array}{l}\text { Restrictions index on inter- } \\
\text { national capital movements }\end{array}$ & IMF & 0.503 & 0.301 & 757 \\
\hline $\begin{array}{l}\text { CI } \\
(1990)\end{array}$ & $\begin{array}{l}\text { Export concentration index, } \\
\text { defined in text }\end{array}$ & UNCTAD & 0.401 & 0.247 & 122 \\
\hline $\begin{array}{l}\mathrm{DC} \\
(1960-94)\end{array}$ & $\begin{array}{l}\text { Financial resources to } \\
\text { private sector, } \% \text { of GDP }\end{array}$ & IMF-IFS & 30.809 & 26.148 & 797 \\
\hline $\begin{array}{l}\text { DIST } \\
(1960-94)\end{array}$ & $\begin{array}{l}\text { Distance to } 20 \text { major trading } \\
\text { economies }\end{array}$ & Barro-Lee & 5.953 & 2.311 & 90 \\
\hline $\begin{array}{l}\text { FDI } \\
(1990-94)\end{array}$ & $\begin{array}{l}\text { Foreign direct investment, } \\
\text { net inflow, } \% \text { of GDP }\end{array}$ & WDI & 1.798 & 2.997 & 126 \\
\hline $\begin{array}{l}\text { IMPDUT } \\
(1975-94)\end{array}$ & $\begin{array}{l}\% \text { tariff revenue to value of } \\
\text { imports. }\end{array}$ & WDI & 12.52 & 9.435 & 459 \\
\hline $\begin{array}{l}\log (G D P) \\
(1960-92)\end{array}$ & (Log of) real per capita GDP & PWT & 7.685 & 1.027 & 853 \\
\hline $\begin{array}{l}\text { LLY } \\
(1960-94)\end{array}$ & Liquid liabilities, $\%$ of GDP & IMF-IFS & 36.534 & 24.461 & 783 \\
\hline $\begin{array}{l}\text { MCAP } \\
(1987-94)\end{array}$ & $\begin{array}{l}\text { Value of listed companies, } \\
\% \text { of GDP }\end{array}$ & $\begin{array}{l}\text { World } \\
\text { Bank1 }\end{array}$ & 26.975 & 40.976 & 217 \\
\hline $\begin{array}{l}\text { Minority } \\
\text { (1990) }\end{array}$ & $\begin{array}{l}\text { Index of minority share } \\
\text { holder protection }\end{array}$ & $\begin{array}{l}\text { World } \\
\text { Bank1 }\end{array}$ & 2.441 & 1.231 & 41 \\
\hline $\begin{array}{l}\text { NTB } \\
(1985)\end{array}$ & $\begin{array}{l}\text { Non-tariff trade barrier cover } \\
\text { ratio }\end{array}$ & $\begin{array}{l}\text { Wacziarg } \\
(1998)\end{array}$ & 13.269 & 13.094 & 113 \\
\hline $\begin{array}{l}\text { OPEN } \\
(1960-94)\end{array}$ & $\begin{array}{l}\text { Exports }+ \text { imports, } \% \text { of } \\
\text { GDP }\end{array}$ & WDI & 63.960 & 37.196 & 811 \\
\hline $\begin{array}{l}\text { POP } \\
(1960-94)\end{array}$ & Thousands of inhabitants & WDI & 28941 & 101986 & 880 \\
\hline $\begin{array}{l}\text { PRIMSH } \\
(1990)\end{array}$ & $\begin{array}{l}\text { Share of primary exports in } \\
\text { total exports }\end{array}$ & WDI & 0.657 & 0.313 & 116 \\
\hline $\begin{array}{l}\text { Regburd } \\
(1990)\end{array}$ & $\begin{array}{l}\text { Index of market unfriendly } \\
\text { practices }\end{array}$ & $\begin{array}{l}\text { World } \\
\text { Bank2 }\end{array}$ & 0.137 & 0.795 & 124 \\
\hline $\begin{array}{l}\text { Rule-of-law } \\
\text { (1990) }\end{array}$ & $\begin{array}{l}\text { ICR index of law and order } \\
\text { tradition }\end{array}$ & $\begin{array}{l}\text { World } \\
\text { Bank1 }\end{array}$ & 7.072 & 2.618 & 41 \\
\hline $\begin{array}{l}\text { Sachs-Warner } \\
(1950-94)\end{array}$ & $\begin{array}{l}\text { Index of openness, } \\
\text { Defined in text }\end{array}$ & SW & 36.928 & 41.373 & 110 \\
\hline $\begin{array}{l}\text { TOT } \\
(1965-92)\end{array}$ & $\begin{array}{l}\text { Growth of merchandise } \\
\text { export prices minus growth } \\
\text { of import prices }\end{array}$ & $\begin{array}{l}\text { Wacziarg } \\
\text { (1998) }\end{array}$ & -0.0067 & 0.066 & 803 \\
\hline
\end{tabular}

PWT stands for Penn World Tables 5.6; WDI for World Bank, World Development Indicators; World Bank1 for the Financial Structure and Economic Development Database; World Bank2 for the World Bank Governance Indicators described in Kaufmann et.al. (1999); UNCTAD for Handbook of International Trade and Development Statistics of UNCTAD; IFC for International Finance Corporation, Emerging Stock Market Factbook; IMF for the IMF's Exchange arrangement and Exchange Restrictions; IMF-IFS for IMF's International Finance Statistics; Barro-Lee for Barro and Lee (1994); SW for Sachs and Warner (1995). SW, PWT and Barro-Lee are available at http://www.nuff.ox.ac.uk/Economics/Growth/datasets.htm. The Financial Structure and Economic Development Database and the Governance Indicators are available at http://www.worldbank.org/research. 
Table A2. Correlation between main variables of interest (1990-94 cross section)

\begin{tabular}{|c|c|c|c|c|c|c|c|c|c|c|}
\hline & OPEN & AREA & DIST & POP & SW & LLY & $\mathrm{DC}$ & MCAP & IMPD. & NTB \\
\hline GDP & $\begin{array}{c}0.164^{*} \\
(107)\end{array}$ & $\begin{array}{c}0.190^{* * *} \\
(107)\end{array}$ & $\begin{array}{c}-0.516^{* * *} \\
(80)\end{array}$ & $\begin{array}{c}-0.043 \\
(109)\end{array}$ & $\begin{array}{c}0.750^{* * *} \\
(106)\end{array}$ & $\begin{array}{c}0.577^{* * *} \\
(104)\end{array}$ & $\begin{array}{c}0.752^{* * *} \\
(106)\end{array}$ & $\begin{array}{c}0.394^{* * *} \\
(69)\end{array}$ & $\begin{array}{c}-0.619^{* * *} \\
(81)\end{array}$ & $\begin{array}{r}-0.090 \\
(113)\end{array}$ \\
\hline OPEN & & $\begin{array}{c}-0.291^{\text {*** }} \\
(130)\end{array}$ & $\begin{array}{c}-0.038 \\
(90)\end{array}$ & $\begin{array}{c}-0.209^{* * * *} \\
(130)\end{array}$ & $\begin{array}{c}0.342^{* * * *} \\
(120)\end{array}$ & $\begin{array}{c}0.459^{* * *} \\
(125)\end{array}$ & $\begin{array}{c}0.221^{* * * *} \\
(127)\end{array}$ & $\begin{array}{c}0.504^{* * *} \\
(76)\end{array}$ & $\begin{array}{c}-0.064 \\
(96)\end{array}$ & $\begin{array}{r}-0.005 \\
(107)\end{array}$ \\
\hline AREA & & & $\begin{array}{c}0.099 \\
(91)\end{array}$ & $\begin{array}{c}0.542^{* * * *} \\
(136)\end{array}$ & $\begin{array}{l}0.018 \\
(122)\end{array}$ & $\begin{array}{r}0.003 \\
(128)\end{array}$ & $\begin{array}{c}0.167^{* * *} \\
(130)\end{array}$ & $\begin{array}{c}0.003 \\
(76)\end{array}$ & $\begin{array}{c}-0.110 \\
(97)\end{array}$ & $\begin{array}{c}-0.032 \\
(111)\end{array}$ \\
\hline DIST & & & & $\begin{array}{c}0.104 \\
(92)\end{array}$ & $\begin{array}{c}-0.409^{* * * *} \\
(91)\end{array}$ & $\begin{array}{c}-0.302^{* * * *} \\
(86)\end{array}$ & $\begin{array}{c}-0.297^{* * * *} \\
(88)\end{array}$ & $\begin{array}{c}-0.054 \\
(61)\end{array}$ & $\begin{array}{c}0.430^{* * * *} \\
(68)\end{array}$ & $\begin{array}{c}0.158 \\
(86)\end{array}$ \\
\hline POP & & & & & $\begin{array}{l}-0.095 \\
(124)\end{array}$ & $\begin{array}{l}0.116 \\
(128)\end{array}$ & $\begin{array}{c}0.143^{*} \\
(130)\end{array}$ & $\begin{array}{c}-0.068 \\
(76)\end{array}$ & $\begin{array}{c}0.028 \\
(97)\end{array}$ & $\begin{array}{l}0.128 \\
(109)\end{array}$ \\
\hline $\begin{array}{l}\text { Sachs- } \\
\text { Warner }\end{array}$ & & & & & & $\begin{array}{c}0.572^{* * * *} \\
(116)\end{array}$ & $\begin{array}{c}0.641^{* * * *} \\
(118)\end{array}$ & $\begin{array}{c}0.436^{* * *} \\
(75)\end{array}$ & $\begin{array}{c}-0.609^{* * * *} \\
(80)\end{array}$ & $\begin{array}{c}-0.086 \\
(105)\end{array}$ \\
\hline LLY & & & & & & & $\begin{array}{c}0.737^{* * * *} \\
(128)\end{array}$ & $\begin{array}{c}0.512^{* * * *} \\
(73)\end{array}$ & $\begin{array}{c}-0.306^{* * *} \\
(95)\end{array}$ & $\begin{array}{l}0.083 \\
(102)\end{array}$ \\
\hline DC & & & & & & & & $\begin{array}{c}0.622^{* * * *} \\
(75)\end{array}$ & $\begin{array}{c}-0.539^{* * * *} \\
(97)\end{array}$ & $\begin{array}{c}-0.025 \\
(104)\end{array}$ \\
\hline MCAP & & & & & & & & & $\begin{array}{c}-0.289^{* *} \\
(67)\end{array}$ & $\begin{array}{c}-0.205 \\
(52)\end{array}$ \\
\hline IMPDUT & & & & & & & & & & $\begin{array}{c}0.192^{*} \\
(89)\end{array}$ \\
\hline
\end{tabular}

*** Indicate significance at 1\%-level, ** at 5\%-level, * at 10\%-level. Figures in parentheses are number of observations. Note that the above correlations are virtually the same for the full sample of observations. ${ }^{\text {a) }}$ The correlations between NTB and the other variables are for the 1985-89 period. 


\section{References}

Agell, J., 1999. On the benefits from rigid labor markets: norms, market failures, and social insurance. Economic Journal 109, F143--F164.

Alesina, A., Wacziarg, R., 1998. Openness, country size and government. Journal of Public Economics 69. 305--321.

Baltagi, B., 1995. Econometric Analysis of Panel Data. Wiley, Chichester.

Barro, R., Lee, J-W., 1994. Data set for a panel of 138 countries. Mimeo Harvard University.

Cassing, J., 1980. Alternatives to protectionism, in: Levenson, J., Wheeler, J.W.

(Eds.), Western Economies in Transition. Westview Press, Boulder.

Cassing, J., Hillman, A., Long, N., 1986. Risk aversion, terms of trade uncertainty and social-consensus trade policy. Oxford Economic Papers 38, 234-242.

Clark, T., Shin, K., 2000. The sources of fluctuations within and across countries, in: Hess, G.D. (Ed.) Intranational Economics. Cambridge University Press: Cambridge. Corden, M., 1974. Trade Policy and Economic Welfare. Clarendon Press, Oxford. Dixit, A., 1987. Trade and insurance with moral hazard. Journal of International Economics 23, 201--220.

Dixit, A., 1989a. Trade and insurance with adverse selection. Review of Economic Studies 56, 235--248.

Dixit, A., 1989b. Trade and insurance with imperfectly observed outcomes. Quarterly Journal of Economics 104, 195--203.

Eaton, J., Grossman, G., 1985. Tariffs as insurance: optimal commercial policy when domestic markets are incomplete. Canadian Journal of Economics 18, 258--272.

Feeney, J., Hillman, A., 2001a. Trade liberalization and asset markets. University of Albany Working Paper.

Feeney, J., Hillman, A., 2001b. Privatization and the political economy of strategic trade policy. International Economic Review 42, 535--556.

Ghosh, A., Wolf, H., 1997. Geographical and sectoral shocks in the U.S. business cycle. NBER Working Paper \#6180.

Gottschalk, P., Moffit, R., 1994. The growth of earnings instability on the US labor market. Brookings Papers on Economic Activity 2, 217--254.

Harrison, A., 1996., Openness and growth: a time-series, cross-country analysis for developing economies. Journal of Development Economics 48, 419--447. 
Hillman, A., 1977. The case for terminal protection for declining industries. Southern Economic Journal 44, 155--160.

Kaufmann, D., Kraay, A. Zoido-Lobaton, P., 1999. Governance matters. World Bank Working Paper \#2196.

King, R., Levine, R., 1993. Finance and growth: Schumpeter might be right. Quarterly Journal of Economics 108, 717--737.

Kraay, A., Loayza, N., Servén, L., Ventura, J., 2000. Country portfolios. Mimeo World Bank.

LaPorta, R., Lopez-de-Silanes, F., Schleifer, A., Vishny, R., 1997. Legal determinants of external finance. Journal of Finance 52, 1131--1150.

Lee, J-W., 1993. International trade, distortions, and long-run economic growth. IMF Staff Papers 40, 299--328.

Levine, R., Zervos, S., 1998. Stock markets, banks, and economic growth. American Economic Review 88, 537-58.

Lewis, K., 1995. Puzzles in international financial markets, in: Grossman, G., Rogoff, K. (Eds.) Handbook of International Economics Vol.3. North-Holland: Amsterdam. Lewis, K., 1996. What can explain the apparent lack of international consumption risk sharing? Journal of Political Economy 104, 267--297.

Newbery, D., Stiglitz, J., 1984. Pareto inferior trade. Review of Economic Studies 51, $1-12$.

Rodriguez, F., Rodrik, D., 1999. Trade policy and economic growth: a skeptic's guide to cross-national evidence. NBER Working Paper \#7081.

Rodrik, D., 1997. Trade, social insurance, and the limits to globalization. NBER Working paper \#5905.

Rodrik, D., 1998. Why do more open economies have bigger governments? Journal of Political Economy 106, 997--1032.

Sachs, J., Warner, A., 1995. Economic reform and the process of global integration. Brookings Papers of Economic Activity 1, 1--118.

Stulz, R., 1999. Globalization of equity markets and the cost of capital. NBER Working Paper \#7021.

Tamirisa, N., 1999. Exchange and capital controls as barriers to trade. IMF Staff Papers 46, 69--88.

Traca, D., 2000. Globalization, wage volatility and the welfare of workers. Mimeo INSEAD. 
Wacziarg, R., 1998. Measuring the dynamic gains from trade. World Bank Policy Research Paper \#2001. 
Table 1. Sachs-Warner index

\begin{tabular}{|c|c|c|c|}
\hline & SW & SW & SW \\
\hline Constant & $\begin{array}{l}0.529 \\
(0.053)\end{array}$ & $\begin{array}{c}20.784^{*} \\
(1.926)\end{array}$ & $\begin{array}{c}14.197 \\
(1.463)\end{array}$ \\
\hline LLY & $\begin{array}{c}0.522^{* * * *} \\
(2.655)\end{array}$ & & \\
\hline MCAP & & $\begin{array}{l}0.241 \\
(1.245)\end{array}$ & \\
\hline DC & & & $\begin{array}{c}0.376^{* * *} \\
(2.351)\end{array}$ \\
\hline GDP & $\begin{array}{l}0.001 \\
(0.637)\end{array}$ & $\begin{array}{l}0.002 \\
(0.689)\end{array}$ & $\begin{array}{l}0.001 \\
(0.637)\end{array}$ \\
\hline AREA & $\begin{array}{l}-0.004 \\
(-0.306)\end{array}$ & $\begin{array}{l}-0.015 \\
(-1.262)\end{array}$ & $\begin{array}{l}-0.010 \\
(-0.829)\end{array}$ \\
\hline POP & $\begin{array}{l}-0.326 \\
(-1.627)\end{array}$ & $\begin{array}{l}-0.238 \\
(-1.149)\end{array}$ & $\begin{array}{c}-0.386^{*} \\
(-1.720)\end{array}$ \\
\hline OECD & $\begin{array}{c}49.708^{* * * *} \\
(3.672)\end{array}$ & $\begin{array}{c}50.733^{* * *} \\
(2.661)\end{array}$ & $\begin{array}{c}44.112^{\text {*** }} \\
(2.929)\end{array}$ \\
\hline LAAM & $\begin{array}{c}10.692 \\
(1.174)\end{array}$ & $\begin{array}{l}7.436 \\
(0.620)\end{array}$ & $\begin{array}{l}2.195 \\
(0.219)\end{array}$ \\
\hline SAFRICA & $\begin{array}{l}-3.167 \\
(-0 . .346)\end{array}$ & $\begin{array}{l}-1.344 \\
(-0.081)\end{array}$ & $\begin{array}{c}-11.689 \\
(-1.158)\end{array}$ \\
\hline EASIA & $\begin{array}{c}38.483^{* * *} \\
(2.558)\end{array}$ & $\begin{array}{c}42.415^{* * *} \\
\quad(2.441)\end{array}$ & $\begin{array}{c}34.026^{* * *} \\
(2.169)\end{array}$ \\
\hline N Countries & 105 & 68 & 107 \\
\hline Adj. $R^{2}$ & 0.612 & 0.522 & 0.607 \\
\hline
\end{tabular}

$* * *$ Indicate significance at $1 \%$-level, ** at 5\%-level,

$*$ at $10 \%$-level. t-statistics based on robust standard errors in parentheses. 
Table 2. Before and after liberalization

\begin{tabular}{l|ccc}
\hline & LLY & DC & MCAP \\
\hline & & & \\
\% Change & 9.5 & 21.7 & 75.6 \\
before lib. & $(37)$ & $(35)$ & $(11)$ \\
\% Change after & 16.3 & 38.2 & 306.1 \\
lib. & $(23)$ & $(21)$ & $(8)$ \\
Initial level: $^{\text {a) }}$ & 49.4 & 37.9 & 23.1 \\
always open $^{\text {Initial level: }}{ }^{\text {a) }}$ & $(19)$ & $(16)$ & $(19)$ \\
always closed & 13.6 & 11.1 & 3.6 \\
& $(17)$ & $(13)$ & $(3)$ \\
\hline & & & \\
\hline
\end{tabular}

Number of observations in parenthesis. ${ }^{\text {a) }} 1960$ for LLY and DC, 1980 for MCAP. 

Table 3. Baseline cross section 1990-94

\begin{tabular}{|c|c|c|c|c|}
\hline & $\log (\mathrm{OPEN})$ & $\log (\mathrm{OPEN})$ & $\log (\mathrm{OPEN})$ & $\log (\mathrm{OPEN})$ \\
\hline $\log (\mathrm{LLY})$ & & $\begin{array}{c}0.412^{* * *} \\
(3.988)\end{array}$ & & \\
\hline $\log (\mathrm{DC})$ & & & $\begin{array}{c}0.197^{* * * *} \\
(2.789)\end{array}$ & \\
\hline $\log (\mathrm{MCAP})$ & & & & $\begin{array}{c}0.138^{* * * *} \\
(4.784)\end{array}$ \\
\hline Log(AREA) & $\begin{array}{l}-0.030 \\
(-0.845)\end{array}$ & $\begin{array}{l}-0.017 \\
(-0.551)\end{array}$ & $\begin{array}{l}-0.025 \\
(-0.774)\end{array}$ & $\begin{array}{l}-0.017 \\
(-0.709)\end{array}$ \\
\hline $\log (\mathrm{DIST})$ & $\begin{array}{c}-0.289^{* * * * *} \\
(-2.801)\end{array}$ & $\begin{array}{c}-0.343^{* * * *} \\
(-3.150)\end{array}$ & $\begin{array}{c}-0.335^{* * * *} \\
(-0.335)\end{array}$ & $\begin{array}{c}-0.486^{* * * *} \\
(-5.161)\end{array}$ \\
\hline $\log (\mathrm{POP})$ & $\begin{array}{c}-0.223^{* * * *} \\
(-4.683)\end{array}$ & $\begin{array}{c}-0.208^{* * * *} \\
(-5.315)\end{array}$ & $\begin{array}{c}-0.223^{* * *} \\
(-5.608)\end{array}$ & $\begin{array}{c}-0.252^{* * *} \\
(-7.790)\end{array}$ \\
\hline $\log (\mathrm{GDP})$ & $\begin{array}{l}0.065 \\
(0.759)\end{array}$ & $\begin{array}{l}-0.052 \\
(-0.658)\end{array}$ & $\begin{array}{l}-0.052 \\
(-0.593)\end{array}$ & $\begin{array}{c}-0.176^{* *} \\
(-2.180)\end{array}$ \\
\hline OECD & $\begin{array}{c}-0.352^{\text {** }} \\
(-2.178)\end{array}$ & $\begin{array}{l}-0.265 \\
(-1.558)\end{array}$ & $\begin{array}{c}-0.357^{* *} \\
(-2.037)\end{array}$ & $\begin{array}{c}-0.273^{*} \\
(-1.650)\end{array}$ \\
\hline LAAM & $\begin{array}{c}-0.298^{* *} \\
(-2.355)\end{array}$ & $\begin{array}{l}-0.010 \\
(-0.064)\end{array}$ & $\begin{array}{c}-0.229^{* * *} \\
(-1.666)\end{array}$ & $\begin{array}{c}-0.205^{*} \\
(-1.677)\end{array}$ \\
\hline SAFRICA & $\begin{array}{l}-0.99 \\
(0.560)\end{array}$ & $\begin{array}{c}0.220 \\
(1.289)\end{array}$ & $\begin{array}{l}0.009 \\
(0.055)\end{array}$ & $\begin{array}{l}0.183 \\
(1.170)\end{array}$ \\
\hline EASIA & $\begin{array}{c}0.525^{* * * *} \\
(3.274)\end{array}$ & $\begin{array}{c}0.610^{* * * *} \\
(3.737)\end{array}$ & $\begin{array}{c}0.458^{* * * *} \\
(2.684)\end{array}$ & $\begin{array}{c}0.533^{* * *} \\
(4.079)\end{array}$ \\
\hline Constant & $\begin{array}{c}6.602^{* * * *} \\
(7.252)\end{array}$ & $\begin{array}{c}5.628^{* * * *} \\
(7.427)\end{array}$ & $\begin{array}{c}6.851^{* * * *} \\
(9.127)\end{array}$ & $\begin{array}{c}8.669^{* * *} \\
(11.250)\end{array}$ \\
\hline N obs. & 77 & 75 & 77 & 55 \\
\hline Adj. $R^{2}$ & 0.552 & 0.635 & 0.592 & 0.793 \\
\hline
\end{tabular}

*** Indicate significance at 1\%-level, $* *$ at 5\%-level, $*$ at $10 \%$-level. t-statistics based on robust standard errors in parentheses. 
Table 4. Additional controls. Dependent variable is $\log (\mathrm{OPEN})$

\begin{tabular}{l|cccc}
\hline & Control: & Control: & Control: & Control: \\
& CAPCONT & CI & PRIMSH & FDI \\
\hline & & & & \\
Log(LLY) & $0.431^{* * *}$ & $0.419^{* * *}$ & $0.385^{* * *}$ & $0.436^{* * *}$ \\
& $(3.069)$ & $(3.297)$ & $(2.856)$ & $(4.301)^{* * *}$ \\
Estimate of & -0.089 & $0.410^{*}$ & 0.196 & $0.101^{* * *}$ \\
control & $(-0.353)$ & $(1.876)$ & $(0.830)$ & $(3.526)$ \\
N obs. & 59 & 73 & 71 & 70 \\
Adj. $\mathrm{R}^{2}$ & .631 & 0.656 & 0.695 & 0.744 \\
\hline \hline & & & & \\
Log(MCAP) & $0.145^{* * *}$ & $0.147^{* * *}$ & $0.157^{* * *}$ & $0.131^{* * *}$ \\
& $(4.777)$ & $(5.782)$ & $(6.066)$ & $(4.167)$ \\
Estimate of & -0.262 & $0.600^{* * *}$ & $0.587^{* * *}$ & $0.068^{* * *}$ \\
control & $(-1.050)$ & $(4.513)$ & $(3.522)$ & $(2.327)$ \\
N obs. & 38 & 54 & 54 & 53 \\
Adj. R & 0.832 & 0.827 & 0.820 & 0.812 \\
\hline & & & & \\
\hline
\end{tabular}

***Indicate significance at $1 \%$-level, $* *$ at 5\%-level, $*$ at $10 \%$-level. t-statistics based on robust standard errors in parentheses. CAPCONT is an index of openness to international financial markets; TOT is the change in terms-of trade; $\mathrm{CI}$ is the export concentration index; PRIMSH is the share of primary resources in exports; FDI is foreign direct investments. All regressions include regional dummies, Log(AREA), $\log ($ POP $), \log ($ DIST), $\log ($ GDP $)$ and a constant. 
Table 5. Panel, LLY and DC 1960-94, MCAP 1975-94.

\begin{tabular}{|c|c|c|c|}
\hline & $\begin{array}{c}\log (\text { OPEN }) \\
\text { FE } \\
\end{array}$ & $\begin{array}{c}\log (\mathrm{OPEN}) \\
\mathrm{FE} \\
\end{array}$ & $\begin{array}{c}\log (\mathrm{OPEN}) \\
\mathrm{FE} \\
\end{array}$ \\
\hline $\log ($ LLY $)$ & $\begin{array}{c}0.185^{* * *} \\
(5.410)\end{array}$ & & \\
\hline $\log (\mathrm{DC})$ & & $\begin{array}{c}0.099^{* * *} \\
(4.269)\end{array}$ & \\
\hline Log(MCAP) & & & $\begin{array}{c}0.060^{\text {*** }} \\
(2.701)\end{array}$ \\
\hline $\log (\mathrm{POP})$ & $\begin{array}{c}-0.202^{* * *} \\
(-2.244)\end{array}$ & $\begin{array}{l}-0.088 \\
(-1.032)\end{array}$ & $\begin{array}{c}0.352^{*} \\
(1.782)\end{array}$ \\
\hline $\log (\mathrm{GDP})$ & $\begin{array}{c}0.191^{\text {**** }} \\
(4.434)\end{array}$ & $\begin{array}{c}0.167^{* * *} \\
(4.269)\end{array}$ & $\begin{array}{l}-0.096 \\
(-0.977)\end{array}$ \\
\hline $\mathrm{N}$ obs & 694 & 706 & 199 \\
\hline $\mathrm{N}$ countries & 121 & 123 & 68 \\
\hline Within $\mathrm{R}^{2}$ & 0.316 & 0.302 & 0.261 \\
\hline
\end{tabular}

*** Indicate significance at 1\%-level, $* *$ at 5\%-level, $*$ at $10 \%$ level. t-statistics based on robust standard errors in parentheses. All regressions include time-period dummies and country-specific fixed effects that are jointly significant. 
Table 6. Additional tests. Dependent variable is $\log (\mathrm{OPEN})$

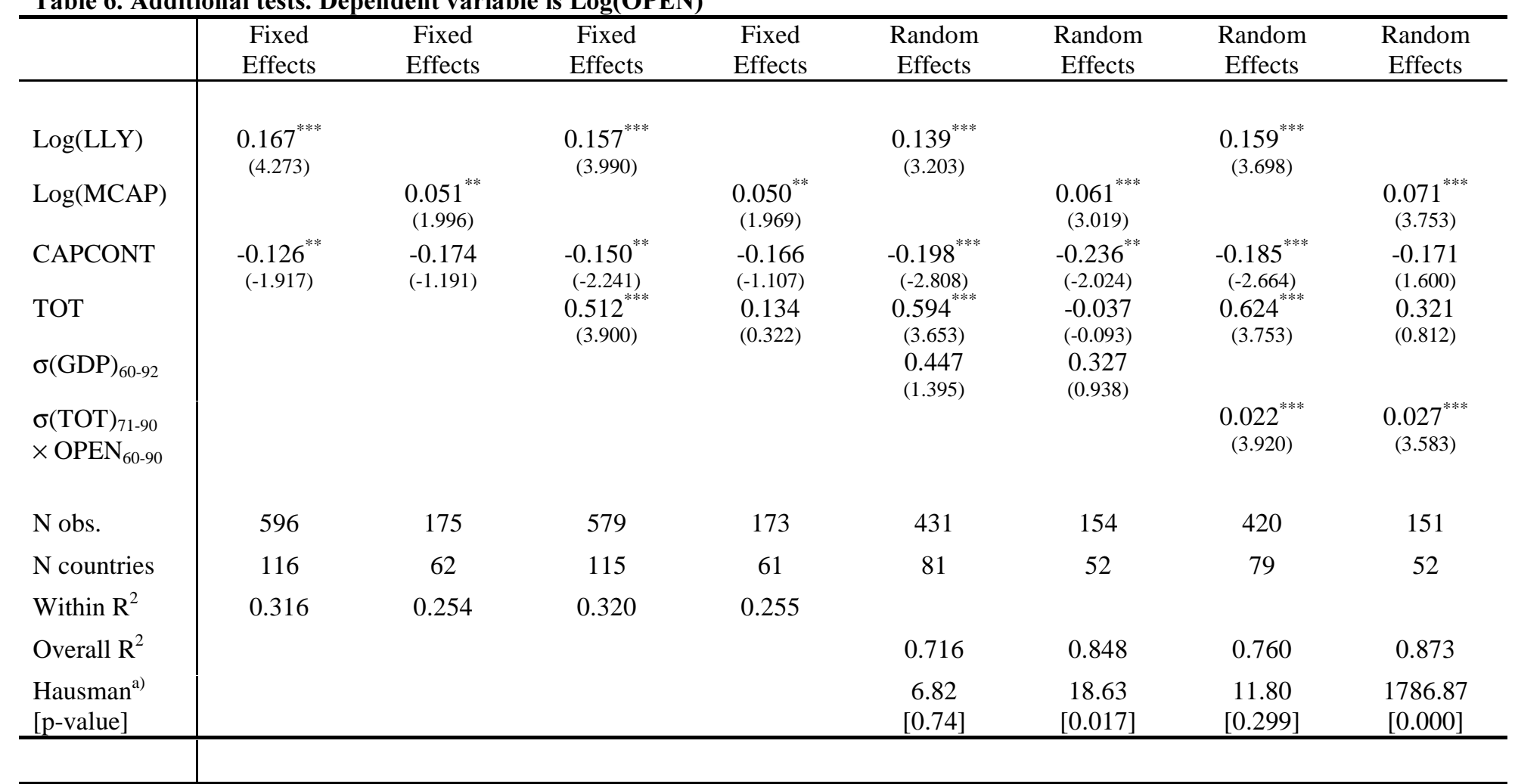

*** Indicate significance at 1\%-level, ** at 5\%-level, * at 10\%-level. t-statistics based on robust standard errors in parentheses. All regressions include $\log (\mathrm{POP}), \log (\mathrm{GDP})$ and time period dummies. The random effects estimates also include regional dummies, Log(AREA), and $\log (\mathrm{DIST}) . \sigma(\mathrm{GDP})_{60-92}$ is the standard deviation of GDP 1960-92, $\sigma(\mathrm{TOT})_{71-90}$ is the standard deviation of log differences in terms of trade $1971-90$, OPEN $_{60-90}$ is average openness 1960-90. ${ }^{\text {a) }}$ The Hausman test statistics is $\chi^{2}$ distributed with the same degrees of freedom as the number of explanatory variables. The p-value indicates at which probability we can reject the hypothesis that the fixed effects and the regressors are correlated. 
Table 7. Alternative measures of openness.

\begin{tabular}{|c|c|c|c|c|}
\hline & $\begin{array}{l}\text { IMPDUT } \\
>\text { mean } \\
\text { GDP/pc. }\end{array}$ & $\begin{array}{l}\text { IMPDUT } \\
<\text { mean } \\
\text { GDP/pc. }\end{array}$ & $\begin{array}{l}\text { NTB } \\
>\text { mean } \\
\text { GDP/pc. }\end{array}$ & $\begin{array}{l}\text { NTB } \\
<\text { mean } \\
\text { GDP/pc. }\end{array}$ \\
\hline $\begin{array}{l}\log (\mathrm{LLY}) \\
\log (\mathrm{MCAP})\end{array}$ & $\begin{array}{l}-1.376 \\
(-0.934) \\
-1.473^{* *} \\
(-2.191)\end{array}$ & $\begin{array}{l}2.270 \\
(1.111) \\
1.508 \\
(0.743)\end{array}$ & $\begin{array}{l}-3.437 \\
(-0.753) \\
-3.075^{*} \\
(-1.790)\end{array}$ & $\begin{array}{l}6.337 \\
(1.233) \\
0.850 \\
(0.428)\end{array}$ \\
\hline \multicolumn{5}{|c|}{$\begin{array}{l}* * * \text { Indicate significance at } 1 \% \text {-level, } * * \text { at } 5 \% \text {-level, } * \text { at } 10 \% \text {-level. t- } \\
\text { statistics based on robust standard errors in parentheses. In columns one } \\
\text { and two, } \log (\mathrm{POP}), \log (\mathrm{GDP}), \text { time period and country specific fixed effects } \\
\text { are also part of the regressions. In columns three and four, } \log (\mathrm{AREA}), \\
\log (\mathrm{POP}), \log (\mathrm{GDP}), \text { and continent dummies are also part of the regression. }\end{array}$} \\
\hline
\end{tabular}


Table 8. Granger causality between LLY/DC/MCAP and OPEN.

\begin{tabular}{|c|c|c|c|}
\hline & $\Delta(\mathrm{OPEN})$ & $\Delta(\mathrm{OPEN})$ & $\Delta(\mathrm{OPEN})$ \\
\hline$\Delta(\mathrm{OPEN})_{\mathrm{t}-1}$ & $\begin{array}{c}0.289 \\
(0.699)\end{array}$ & $\begin{array}{c}-0.082 \\
(-0.222)\end{array}$ & $\begin{array}{c}1.231 \\
(0.363)\end{array}$ \\
\hline$\Delta(\mathrm{LLY})_{\mathrm{t}-1}$ & $\begin{array}{l}0.277^{* *} \\
(2.521)\end{array}$ & & \\
\hline$\Delta(\mathrm{DC})_{\mathrm{t}-1}$ & & $\begin{array}{l}0.148^{* *} \\
(2.102)\end{array}$ & \\
\hline$\Delta(\mathrm{MCAP})_{\mathrm{t}-1}$ & & & $\begin{array}{c}-0.126 \\
(-0.406)\end{array}$ \\
\hline \multirow[t]{2}{*}{$\mathrm{N}$ obs } & 476 & 403 & 83 \\
\hline & $\Delta$ (LLY) & $\Delta(\mathrm{DC})$ & $\Delta$ (MCAP) \\
\hline$\Delta(\mathrm{LLY})_{\mathrm{t}-1}$ & $\begin{array}{l}0.430^{\text {** }} \\
(2.233)\end{array}$ & & \\
\hline$\Delta(\mathrm{DC})_{\mathrm{t}-1}$ & & $\begin{array}{l}0.462^{* *} \\
(2.193)\end{array}$ & \\
\hline$\Delta(\mathrm{MCAP})_{\mathrm{t}-1}$ & & & $\begin{array}{l}1.129^{* *} \\
(2.119)\end{array}$ \\
\hline$\Delta(\mathrm{OPEN})_{\mathrm{t}-1}$ & $\begin{array}{l}0.115^{* * *} \\
(2.646)\end{array}$ & $\begin{array}{l}0.212^{* * *} \\
(3.427)\end{array}$ & $\begin{array}{l}1.565^{\text {*** }} \\
(2.935)\end{array}$ \\
\hline $\mathrm{N}$ obs. & 390 & 3.427 & 34 \\
\hline
\end{tabular}

***Indicate significance at 1\%-level, ** at 5\%-level, * at 10\%-level.t-statistics based on robust standard errors in parentheses. The lagged difference of the dependent variable is instrumented using the twice-lagged difference and the twice-lagged level of the dependent variable. 
Table 9. Instrumental variables 1990-94

\begin{tabular}{|c|c|c|c|}
\hline & $\log (\mathrm{OPEN})$ & $\log (\mathrm{OPEN})$ & $\log (\mathrm{OPEN})$ \\
\hline $\log (\mathrm{LLY})$ & $\begin{array}{l}0.606^{* *} \\
(1.993)\end{array}$ & & \\
\hline $\log (\mathrm{DC})$ & & $\begin{array}{l}0.606^{* *} \\
(2.011)\end{array}$ & \\
\hline $\log (\mathrm{MCAP})$ & & & $\begin{array}{c}0.276^{*} \\
(1.866)\end{array}$ \\
\hline $\mathrm{N}$ obs. & 36 & 38 & 37 \\
\hline $\begin{array}{l}\mathrm{R}^{2} \text { of residuals } \\
\text { on instruments } \\
\text { OIR-test }^{\mathrm{a})}\end{array}$ & 0.004 & 0.0001 & 0.053 \\
\hline
\end{tabular}

$* * *$ Indicate significance at 1\%-level, ** at 5\%-level, * at 10\%-level. $\mathrm{t}$-statistics based on robust standard errors in parentheses. Regressions include constant, $\log ($ GDP), $\log ($ AREA $), \log ($ DIST), $\log (\mathrm{POP})$, and regional dummies. Instruments are an index of minority shareholder rights, the 'rule of law' index by $I C R$, and the number of assassinations per million inhabitants. ${ }^{\text {a) }}$ The null hypothesis of the overidentification test is that the instruments are not correlated with the residuals from the second stage regression. Critical values for the test ( 2 d.f.): $10 \%=4.61,5 \%=5.99$. 


\section{Footnotes}

${ }^{1}$ Dixit $(1987,1989 \mathrm{ab})$ is a dissenting voice in this literature. When explicitly modeling the reasons behind the absence of insurance markets, he finds the scope for government intervention to be limited.

${ }^{2}$ Traca (2000) shows theoretically that we have reasons to expect trade to increase income volatility. Further empirical evidence for this view is given in Gottschalk and Moffit (1994), and Ghosh and Wolf (1997).

${ }^{3}$ In some cases, access to international asset markets can reduce lobbying pressure in the Feeney-Hillman model. For this to happen, an asymmetry of assets that can be traded must be present between sectors. If we interpret the share of tradable capital as the degree of financial development, the assumption of asymmetries between sectors is quite odd.

${ }^{4}$ Traca cites empirical evidence by Gottschalk and Moffit (1994) to motivate his model.

${ }^{5}$ The last point is important because if international risk sharing is constant over time, this effect will be captured by the country specific fixed effects when running panel regressions.

${ }^{6}$ Stulz (1999) finds more recent evidence that globalization has so far had quite a limited impact on the cost of capital to firms. Kraay et al. (2000) show that countries' foreign asset positions have been very persistent over time and have mainly taken the form of loans rather than equity during the 1966-1997 period. Both these papers indicate that international capital markets are not yet well integrated.

${ }^{7}$ We thank an anonymous referee for making this point.

${ }^{8}$ There are of course other factors that can explain financial liberalization. One is that the gains from the removal of capital restrictions can increase after an increase in trade since the volume of international transactions has gone up. Another reason (not related to trade) is that governments running deficits might want to free capital movements in order to get access to international credit more cheaply.

${ }^{9}$ The inclusion of per capita GDP in the trade policy equation can be motivated by other arguments as well: Industrial specialization and dependence on imported intermediate goods are just some factors likely to increase with GDP.

${ }^{10}$ In Table A2, the correlations in the 1990-94 cross section are presented. The results are essentially unchanged when considering the full sample of observations. 
${ }^{11}$ The indicators are 'Bilateral payments', 'Restrictions for payments on capital transactions', 'Restrictions for payments on current account transactions', and 'Proscribed currency/payment arrears'. See Lewis (1996) for a thorough discussion of the data. Using alternate versions of this index does not affect the results to any significant degree. However, when using the widest measure (capital transactions) by itself, this variable loses its significance. Since most countries have some restrictions on international transactions, this should be of no surprise.

${ }^{12}$ The results are qualitatively the same when using a 10-year period rather than a five-year period.

${ }^{13}$ It is also possible that investments increase after liberalization (Wacziarg 1998), and that the proxies of financial development are related to investments. However, controlling for the investment share of GDP does not affect the results.

14 This argument does not apply to the special case of CARA utility.

${ }^{15}$ For the log-specifications, the adjusted $\mathrm{R}^{2}$ without the proxies for financial development are $0.55,0.55$, and 0.74 , for the respective sample. This means that the increase in explanatory power from adding financial proxies is between 4 and 8 percentage points.

${ }^{16}$ The point estimate is higher in 1990 than any other time period. The coefficients on DC and MCAP are more stable over time.

${ }^{17}$ The results are essentially the same for DC. The reason why both LLY and MCAP are presented is that the sample differs quite a bit between the variables.

${ }^{18}$ The Gini-Hirschman index of concentration over 239 three-digit SITC export categories, calculated by UNCTAD.

${ }^{19}$ We have also controlled for the investment share to GDP, human capital, and population density but this does not affect the results. This is further evidence that the measures of financial development are not proxies for investments (compare note 14). ${ }^{20}$ The great exception in the difference in explanatory power - the 'within' $\mathrm{R}^{2}$ that applies to fixed effect estimations and the 'overall' $\mathrm{R}^{2}$ applying to random effects. The overall $\mathrm{R}^{2}$ is between 0.7-0.8 depending on sample and specification. Since some of our control variables for trade are time invariant (DIST, AREA, regional dummies), it should be of no surprise that the within $\mathrm{R}^{2}$ is much lower than the overall $\mathrm{R}^{2}$. ${ }^{21}$ All specifications have been estimated for DC as well. These regressions are virtually identical to the LLY-regressions so we do not present the results. 
${ }^{22}$ It should also be noted that the effect of aggregate risk, measured in these ways, is captured in the country specific fixed effects when running fixed effects estimations.

${ }^{23}$ A combined measure of import- and export duty ratios is also constructed:

TARIFFS $=(1+$ IMPDUT $)(1+$ EXPDUT $)-1)$, as suggested in Rodriguez and Rodrik (1999). This measure is highly correlated with IMPDUT and hence, the results are essentially equivalent.

${ }^{24}$ The dynamic panel data problem and its solutions are discussed in Baltagi (1995), chapter 8 .

${ }^{25}$ As explained above, all time-invariant variables are captured in the country specific fixed effects.

${ }^{26}$ In the IV-samples, the OLS-estimates for LLY, DC, and MCAP are 0.23, 0.15, and 0.21 respectively.

${ }^{27}$ This test assesses if the instruments have an independent effect of openness to trade beyond their ability to explain cross-country variation in financial development. The test statistic is obtained by running the residuals from the second stage regression on the instruments and multiplying the $\mathrm{R}^{2}$ from this regression with the number of observations. Under the null-hypothesis that the instruments are not correlated with the error term, the test is distributed $\chi^{2}$ with $(j-k)$ degrees of freedom, where $j$ is the number of instruments, and $k$ the number of variables instrumented for. 